die ungeordnete Struktur statischer oder dynamischer Natur ist. Mit der Festkörperkernresonanz lassen sich die beiden Fälle unterscheiden: Wenn für einen Kern z. B. zwei Plätze im Kristallgitter in Frage kommen, so beobachtet man im Fall statischer Unordnung zwei axialsymmetrische Tensoren. Wenn die Unordnung hingegen dynamisch und die Zeitskala der Dynamik kürzer als etwa $10^{-4} \mathrm{~s}$ ist, dann beobachtet man nur einen Tensor, der im allgemeinen nicht mehr axialsymmetrisch ist. Wenn $D_{i k}$ als Funktion der Temperatur gemessen wird, erhält man nicht nur Struktur-, sondern auch kinetische Information. Konkrete Beispiele dieser Art werden diskutiert werden.

Quadropolkopplungstensoren $V_{i}$ sollen speziell für den Fall von Deuteronen betrachtet werden. Es ist eine Erfahrungstatsache, die aber auch durch MO-Rechnungen gestützt wird, daß die $V_{i}$ von Deuteronen näherungsweise achsialsymmetrisch sind und daB die Richtung der ausgezeichneten Hauptachse von $V_{i}$ näherungsweise parallel zu der $X-D_{i}(X=\mathrm{C}, \mathrm{O}, \mathrm{N}$ etc. $)$ Bindungsrichtung ist. Die Abweichungen zwischen diesen Richtungen betragen typischerweise weniger als $1^{\circ}$. Allerdings gibt es bislang nur sehr wenige echte Messungen dieser Abweichungen. In Kristallen einfacher Moleküle können die ausgezeichneten Hauptachsen der $V_{i}\left(D_{i}\right)$ ohne großen Aufwand bis auf $0.5^{\circ}$ genau und besser relativ zu den Kristallachsen gemessen werden. Allerdings sind dazu deuterierte Kristalle erforderlich. Das bedeutet, daß C-D, O-D, N-D etc. Bindungsrichtungen in solchen Kristallen mittels Deuteronenresonanz um etwa einen Faktor 5 genauer bestimmt werden können als mit Röntgenmethoden. Vergleichbare Genauigkeiten werden meines Erachtens nur mit Neutronenstreuung erreicht. Verschiedene Beispiele für die $\mathrm{Be}$ stimmung von Bindungsrichtungen mittels Deuteronenresonanz werden angegeben werden. Es wird vorgeschlagen, X-D Bindungsrichtungen, die mittels Deuteronenresonanz gemessen wurden, als Nebenbedingungen in die Gleichungssysteme einzugeben, mit denen in der Röntgenkristallographie Strukturen berechnet werden. Dies sollte definitiv zu einer Verbesserung der Genauigkeit führen, mit der die Positionen von Wasserstoffatomen in Kristallgittern angegeben werden können.

Der Zusammenhang zwischen Abschirmtensoren verschiedener Kerne, vor allem ${ }^{1} \mathrm{H}$ und ${ }^{13} \mathrm{C}$, und der Molekülgeometrie wird betrachtet werden. Anhand eines speziellen Beispiels $\left(\mathrm{PbHPO}_{4}, \mathrm{Bleiresonanz}\right)$ werde gezeigt, daß Kernresonanz- und Streumethoden zu verschiedenen Aussagen über die Symmetrie der Einbaulage eines Kernes kommen können. Die Diskrepanz wird auf die unterschiedliche Zeitskala der Resonanz- und Streuexperimente zurückgeführt. Es wird argumentiert, daß beide Arten von Experimenten zusammen einen tieferen Einblick in die Struktur einer Substanz erlauben, als jedes Experiment für sich allein.

\section{Applications of two-dimensional solid state NMR}

\author{
W. S. Veeman, A. P. M. Kentgens, and R. Janssen
}

Laboratory of Molecular Spectroscopy, Faculty of Science, University of Nijmegen, Toernooiveld, NL-6525 ED Nijmegen, The Netherlands

\section{Anwendungen der zweidimensionalen Festkörper-KMR}

High resolution solid state NMR has become a routine analytical technique in many industrial and university laboratories Two-dimensional solid state NMR has not yet reached that status but the two following applications will emphasize the increased information content of two-dimensional NMR spectra for solid state NMR studies.

\section{Slow molecular motions in solids}

The NMR frequency of a carbon-13 nuclear spin in a solid is not only determined by the strength of the external magnetic field but due to the anisotropic chemical shift also by the orientation relative to molecular axes. Therefore, any reorientation of a chain segment or of a side group of a polymer for instance changes the resonance frequency of a carbon nuclear spin in this chain or side group. Molecular motions with a time scale longer than the inverse of the NMR line width are usually not detected by one-dimensional NMR but a two-dimensional exchange NMR experiment can be used. Here, the resonance frequency of a particular spin is measured during the evolution period, $\omega_{e}$, and during the detection period, $\omega_{d}$. Both the evolution and detection period are assumed to be much shorter than the characteristic time scale of the motion, but the mixing period which separates the detection time from the evolution period should be of the same order of magnitude. When during this mixing time no molecular reorientations have occurred, then for every spin $\omega_{e}=\omega_{d}$ and in the two-dimensional spectrum only intensity is found at the diagonal. Off-diagonal intensity is evidence for molecular reorientations during the mixing period if other possible causes like spin diffusion can be neglected.

Usually for resolution and sensitivity reasons magic angle spinning is needed to obtain spectra of solid polymers. This also introduces reorientations of molecules relative to the external magnetic field and, if the MAS frequency is high, even eliminates the chemical shift anisotropy and destroys the information about the intrinsic molecular reorientations. A two-dimensional, slow MAS experiment has been devised [1] which separates the coherent sample reorientations due to MAS from the incoherent, intrinsic molecular reorientations due to molecular motions. In the crystalline regions of polyoxymethylene slow chain reorientations have been detected with, at room temperature, a characteristic time of the order of $10 \mathrm{~s}$ [2]. From the two-dimensional spectra it can be concluded that the helical chains in polyoxymethylene can rotate over about $200^{\circ} \mathrm{C}$ [3].

\section{Quadrupole nutation NMR in solids}

Many materials contain nuclei which have in addition to a magnetic dipole moment an electric quadrupole moment. In an NMR experiment these nuclei interact not only with the external magnetic field via their magnetic moment but also with internal electric field gradients via the quadrupol moment. The NMR spectrum, consequently, is effected by the electric quadrupole interaction and can give information about the electric field gradients sensed by the nucleus under study. Very often the quadrupole interaction is so large relative to the Zeeman interaction that in a microcrystaline or amorphous solid sample, the anisotropic quadrupole interaction severely broadens the NMR lines. For half-integer quadrupolar spins (spin quantum number $\mathrm{I}=3 / 2,5 / 2,7 / 2, \ldots)$ the situation is more favourable since the $m=1 / 2 \leftrightarrow m=-1 / 2$ transition for these nuclei is broadened by the quadrupole interaction only in second-order perturbation theory [4]. With or without magic angle spinning the line shape of this $1 / 2 \leftrightarrow-1 / 2$ transition characteristically depends on the quadrupole parameters. In favourable cases these parameters can be directly derived from the NMR lineshape and give infor- 
mation about local symmetry [5]. Usually, however, chemical shift effects and distributions of quadrupole parameters smear out the characteristic line shape.

For these cases a two-dimensional experiment can give additional information. Here the precession of quadrupolar spins is studied in two situations: in the detection period the magnetization precesses around the external magnetic field (in the laboratory frame) and in the evolution period during which an rf pulse is applied, the spins precede (nutate) around the if field in the rotating frame. If we assume that the Zeeman interaction is much larger than the quadrupole interaction, then in the laboratory frame we have a high-field [4] situation, while in the rotating frame the quadrupole interaction is in general of the same order of magnitude as the $\mathrm{rf}$ field. This nutation experiment [6-9] gives very characteristic two-dimensional spectra where chemical shift effects are eliminated in one dimension of the spectrum while the quadrupole interaction contributes in first order. In several examples nutation NMR has been applied to ${ }^{27} \mathrm{Al}$ and ${ }^{23} \mathrm{Na}$ spins in zeolites. It has especially been shown how the effect of hydration on the ${ }^{23} \mathrm{Na}$ spectra of $\mathrm{NaA}$ zeolite can be followed by this two-dimensional technique.

\section{References}

1. de Jong AF, Kentgens APM, Veeman WS (1984) Chem Phys Lett 109:337

2. Kentgens APM, de Jong AF, de Boer E, Veeman WS (1985) Macromolecules 18:1043

3. Kentgens APM, Veeman WS, to be published

4. Abragam A (1961) The principle of nuclear magnetism. Oxford University Press, Oxford

5. Scholle KFMGJ, Veeman WS (1985) Zeolites 5:118

6. Samoson A, Lippmaa E (1983) Chem Phys Lett 100:205; (1983) Phys Rev B 28:6567

7. Geurts FMM, Kentgens APM, Veeman WS (1985) Chem Phys Lett 120:206

8. Kentgens APM, Lemmens JJM, Geurts FMM, Veeman WS (1987) J Magn Res 71:62

9. Troniker A, Man PP, Theveneau H, Papon P (1985) Solid State Comm 55:929. - Man PP, Theveneau H, Papon P (1985) J Magn Res 64:271. - Man PP (1985) J Magn Res $67: 78$

Fresenius Z Anal Chem (1987) 327:63-64 (C) Springer-Verlag 1987

\section{The structural basis of photosynthetic light reactions in bacteria}

\section{Robert Huber}

Max-Planck-Institut für Biochemie, D-8033 Martinsried, Federal Republic of Germany

\section{Strukturelle Grundlage der photosynthetischen Lichtreaktionen in Bakterien}

In photosynthesis light energy is absorbed and subsequently converted into chemical energy stored in energy-rich compounds. Photosynthesis occurs in bacteria and green plants in specialized membranes which are either infoldings of the cell membrane (in prokaryotes) or of the chloroplast membrane (in eukaryotes). The primary reactions of photosynthesis are light absorption, light energy conduction and charge separation across the membrane. They occur in protein pigment complexes with a very high quantum efficiency. A large amount of functional data of these reactions in bacteria has been accumulated. The recent crystal structural studies at high resolution of the light harvesting complexes of cyanobacteria (phycobilisomes) and the reaction center of the purple bacterium Rhodopseudomonas viridis provide a basis for an understanding of the underlying physical principles. The original stud- ies of phycobilisome components and of the reaction center have been described by Schirmer et al. $[1,2]$, by Deisenhofer et al. [3, 4], and Michel et al. [5], respectively. Short reviews are available $[6,7]$. Recently it was shown that the reaction centers of Rps. viridis and Rps. sphaeroides are closely related in structure [8].

\section{References}

1. Schirmer T, Bode W, Huber R, Sidler W, Zuber H (1985) J Mol Biol 184:257

2. Schirmer T, Huber R, Schneider M, Bode W, Miller M, Hackert ML (1986) J Mol Biol 188:651

3. Deisenhofer J, Epp O, Miki K, Huber R, Michel H (1984) J Mol Biol 180:385

4. Deisenhofer J, Epp O, Miki K, Huber R, Michel H (1985) Nature 318:618

5. Michel H, Epp O, Deisenhofer J (1986) EMBO J 5:2445

6. Deisenhofer J, Michel H, Huber R (1985) Trends Biochem Sci 10:243

7. Deisenhofer J, Huber R, Michel H (1986) Nachr Chem Tech Lab 34:417

8. Allen JP, Feher G, Yeates TO, Rees DC, Deisenhofer J, Michel H, Huber R (1986) Proc Natl Acad Sci USA 83: 8589

Fresenius Z Anal Chem (1987) 327:64 (C) Springer-Verlag 1987 